\title{
Analiza procesów magazynowania biowodoru jako paliwa
}

\begin{abstract}
Wprowadzenie
Magazynowanie wodoru nie jest problemem występującym w przemyśle chemicznym, gdyż jest on wytwarzany na miejscu i dostarczany w miarę potrzeb do instalacji (, just-in-time"). Problem ten jest obecny natomiast w motoryzacji, gdzie wodór powinien by „zatankowany” do pojazdu w ilości niezbędnej do przejechania określonej liczby kilometrów. Magazynowanie wodoru w pojeździe jest znacznie większym problemem niż magazynowanie paliw płynnych (LPG, benzyny, oleju napędowego). Zgodnie z założeniami pojazd powinien by wyposażony w zbiornik zdolny pomieścić $5-13 \mathrm{~kg}$ wodoru, co daje możliwość przejechania bliska pięciuset kilometrów z pełnym obciążeniem. Założenia te dotyczą samochodów osobowych lub lekkich samochodów dostawczych z silnikiem elektrycznym stosowanym jako napęd, który zasilany jest wodorem z zainstalowanych w pojeździe ogniw paliwowych. ${ }^{2}$

W dwóch wariantach zasilania ogniwa wodorem: sprężonym do ciśnienia $250 \mathrm{~atm}$. (w temperaturze $20^{\circ} \mathrm{C}$ ) lub ciekłym, istotna jest wartość opałowa, która wynosi odpowiednio 600 i $1650 \mathrm{MJ} / \mathrm{dm}^{3}$. Gęstość wodoru w postaci gazowej i ciekłej jest znana zatem można wyliczyć pojemność zbiorników wodoru w pojeździe. W wyżej wymienionym przypadku zbiornik na wodór ciekły powinien mieć pojemność $71 \ldots 184 \mathrm{dm}^{3}$, a na wodór gazowy pod ciśnieniem 250 atm, $250 \ldots 650 \mathrm{dm}^{3}$. Z porównania obu tych parametrów użytkowych paliwa przyszłościowego z obecnie stosowaną do silników spalinowych benzyną oraz równowartości energetycznej obu paliw wynika, że zbiornik benzynowy powinien mieć pojemność $18 \ldots 47 \mathrm{dm}^{3}$. W praktyce jednak, ze względu na mniejsza sprawność silnika spalinowego od sprawności ogniwa paliwowego, pojemność zbiornika benzynowego może wynosić $25 . . .70 \mathrm{dm}^{3}$.
\end{abstract}

J. SuRYgaŁa, Wodór jako paliwo, WNT, Warszawa 2008, s. 82.

2 www1.eere.energy.gov. 
Rysunek 1 przedstawia zależność gęstości energii od rodzaju paliwa i stopnia sprężenia. Obecnie do magazynowania stosowane są zbiorniki na wodór sprężony, wodór ciekły, pojemniki z wodorkami metali, materiały węglowe oraz połączenia chemiczne o dużej zawartości wodoru.

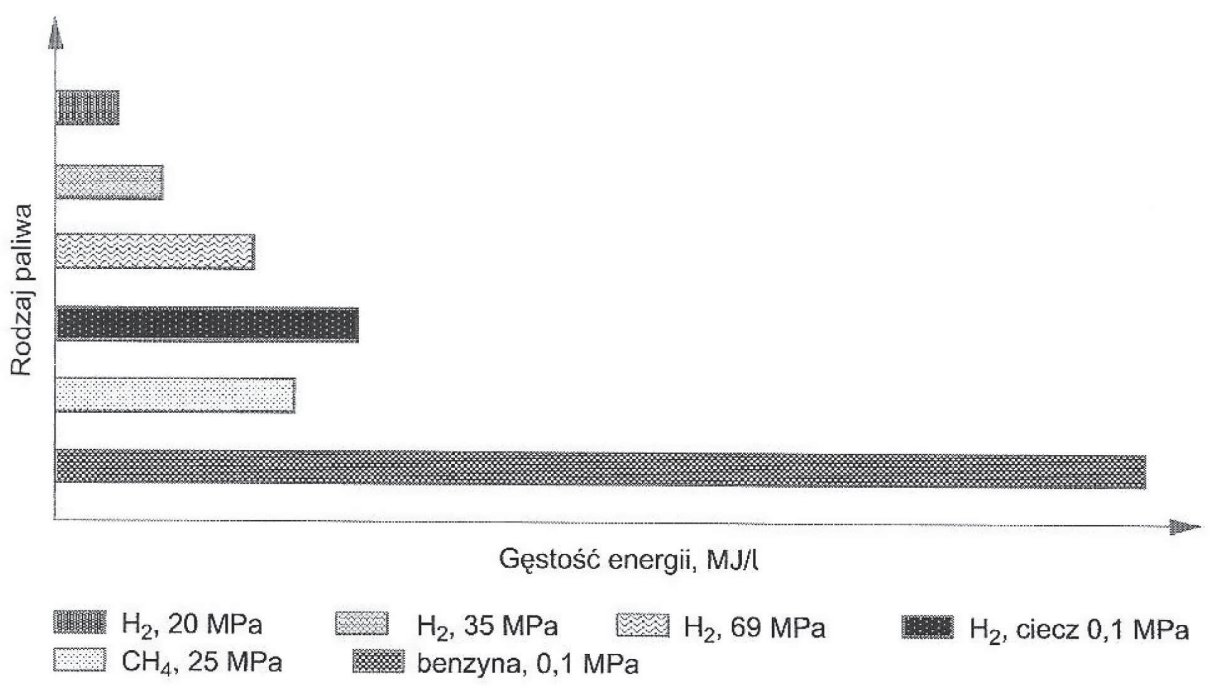

Rys. $1^{3}$ Zależność gęstości energii od rodzaju paliwa i ciśnienia

Magazynowanie wodoru w formie gazu, cieczy wodorków metali lub sorbentów o dużej powierzchni w układzie paliwowym pojazdu jest nazywane „odwracalnym", ponieważ powtórne napełnienie lub regeneracja zachodzi w samochodzie. Natomiast w przypadku wodoru związanego chemicznie, gdzie reakcja zachodząca w pojemniku $\mathrm{H}_{2}$, regeneracja dostawcy wodoru nie jest możliwa w samochodzie, ponieważ materiał, z którego wyczerpany został wodór, regenerowany jest poza pojazdem.

Wodorki metali są to materiały stałe charakteryzujące się odwracalnym sposobem magazynowania wodoru. W przypadku wodorków metali, wodór jest absorbowany bezpośrednio do materiału. W prostych krystalicznych wodorkach metali absorpcja zachodzi przez przyłączanie wodoru atomowego w połączenia międzywęzłowe sieci krystalicznej metalu. W tej postaci duże ilości wodoru mogą być zmagazynowane w małych objetosciach, pod niskim ciśnieniem i w temperaturze bliskiej temperaturze pokojowej. Ta metoda pozwala na osiągniecie większej gęstości objętościowej $\mathrm{H}_{2}$ w wodorku od gęstości cieczy, ponieważ cząsteczka wodoru jest zdysocjowana na atomy wewnątrz sieci.

3 J. Suryga£a, Wodór jako paliwo, WNT, Warszawa 2008, s. 83. 
Kolejnym materiałem magazynującym wodór są sorbenty węglowe. Wykorzystują one zjawisko adsorpcji, przy czym wyróżnia się sorpcję fizyczna i chemisorpcję, które bazują na energetycznych mechanizmach adsorpcji. Sorpcję fizyczna odróżnia od chemisorpcji, między innymi mniejsza siła wiązania. W celu zmaksymalizowania pola powierzchni dostępnego dla cząsteczek wodoru i ułatwienia przebiegu procesów sorpcji i desorpcji wodoru z materiału w procesach sorpcyjnych stosuje się materiały o dużej porowatości.

$\mathrm{W}$ przypadku magazynowania wodoru gazowego potrzebne są zbiorniki na ciśnienie 350 lub $700 \mathrm{~atm}$. Ciśnienie zbiorników stosowanych obecnie w pojazdach doświadczalnych nie przekracza $250 \mathrm{~atm}$. Magazynowanie wodoru w stanie ciekłym wymaga temperatury kriogenicznej, tzn. niższej niż $200 \mathrm{~K}\left(-73^{\circ} \mathrm{C}\right)$, ze względu na temperaturę wrzenia wodoru pod ciśnieniem atmosferycznym, która wynosi $20 \mathrm{~K}\left(-253^{\circ} \mathrm{C}\right)$.

Działania wodorków chemicznych polega na uwalnianiu związanego chemicznie wodoru. Reakcja ta zachodzi pod wpływem reakcji chemicznej lub termicznie. Reagentem jest często woda lub alkohol. „Zużyte paliwo” lub produkt uboczny są po wyczerpaniu wodoru regenerowane poza pojazdem. Zarówno w przypadku tworzenia jak i rozkładu w wodorkach chemicznych występują odpowiednie reakcje chemiczne. Dla reakcji, które mogą przebiegać odwracalnie w pojeździe, uwalnianie i magazynowanie wodoru zachodzi przez proste odwrócenie reakcji chemicznej na skutek zmiany temperatury, ciśnienia lub innego parametru kinetycznego. Jednak w większości przypadków reakcja uwalniania wodoru nie jest reakcja odwracalna na skutek umiarkowanej zmiany ciśnienia lub temperatury.

\section{Procesy magazynowania wodoru (biowodoru)}

Gazowy wodór może być magazynowany w zbiornikach ciśnieniowych. Sprężenie wodoru powoduje zwiększenie gęstości energii. Dolna wartość opałowa wodoru gazowego pod ciśnieniem $1 \mathrm{~atm}$ wynosi $10,05 \mathrm{GJ} / \mathrm{m}^{3}$, pod ciśnieniem 200 atm ma wartość $1820 \mathrm{GJ} / \mathrm{m}^{3}$, a sprężonego wodoru do $690 \mathrm{~atm}$, wynosi $4500 \mathrm{GJ} / \mathrm{m}^{3}$.

Obecnie w skali doświadczalnej wodór gazowy transportowany jest od wytwórcy do dystrybutora $\mathrm{w}$ zbiornikach ciśnieniowych rozmieszczonych w pojazdach ciężarowych o masie całkowitej $40 \mathrm{Mg}$. Zwykle masa transportowanego wodoru wynosi $530 \mathrm{~kg}$, a ciśnienie ma wartość $20 \mathrm{MPa}$.

Stacjonarne magazynowanie wodoru obecnie odbywa się w zbiornikach stalowych na ciśnienie $5 \mathrm{MPa}$, o średnicy 8m, długości 7, 9 lub 19 m i maksymalnej pojemności $1300 \ldots 4500 \mathrm{~m}^{3}$. Zbiorniki wodoru sprężonego instalowane w pojazdach starszego typu wykonane ze stopów metali umożliwiają na stosowanie ciśnienia w zakresie $15 \ldots 25 \mathrm{MPa}$. Budowane obecnie zbiorniki wykonane są z włókien węglowych lub aluminium i kompozytów, pozwalają uzyskać ciśnienia 
rzędu 20, 24,8 i $30 \mathrm{MPa} .{ }^{4}$ Dostępne są zatem na rynku zbiorniki o pojemności 501 lub $390 \mathrm{l}$ o średnicach odpowiednio $39 \mathrm{~cm}$ lub $33,5 \mathrm{~cm}$.

Zbiorniki takie posiadają warstwę wewnętrzną wykonana z polimeru o dużej masie cząsteczkowej, która umiemozliwia przenikanie wodoru przez ścianki zbiornika. Warstwa zewnętrzna natomiast wykonana jest z materiału o dużej wytrzymałości na rozrywanie. Pomiędzy tymi dwiema warstwami jest jeszcze jedna $\mathrm{z}$ tkaniny węglowej lub żywicy epoksydowej. Zbiornik jest także wyposażony w zainstalowany wewnątrz czujnik i regulator ciśnienia na 700 atm oraz czujnik temperatury. Produkowane obecnie zbiorniki mają kształt cylindryczny, ale dąży się do opracowania zbiorników o kształcie dopasowanym do karoserii samochodowej i odpowiedniej wygody pasażerów. ${ }^{5}$

Zasięg pojazdu napędzanego sprężonym wodorem zależy od typu pojazdu, pojemności zbiornika i oraz ciśnienia wodoru. Odległość jaką może pokonać pojazd do kolejnego tankowania można zwiększyć podwyższając pojemność oraz ciśnienie $\mathrm{H}_{2}$. Jednocześnie jednak koszty staną się większe, a przestrzeń w pojeździe mniejsza. Zatem kluczowymi parametrami magazynowania wodoru w zbiornikach ciśnieniowych jest objętość, ciśnienie $\mathrm{H}_{2} \mathrm{i}$ koszty. Najmniejsza gęstość magazynowania wodoru przy $0,5 \mathrm{kWh} / \mathrm{kg}$ występuje w przypadku zbiorników stalowych, pracujących pod ciśnieniem $20 \mathrm{MPa}$, a największa w przypadku zbiorników pełnokompozytowych o ciśnieniu pracy 24,8 MPa.

W wyniku podwyższenia maksymalnego ciśnienia roboczego zbiornika następuje:

- zwiększenie czasu napełniania zbiornika na stacji paliw,

- zwiększenie ilości energii potrzebnej do sprażenia,

- konieczność odprowadzania większej ilości ciepła sprężania.

Zatem masa, objętość, ciśnienie i komfort wymagają optymalizacji. Koszt samego zbiornika ciśnieniowego zależy w dużym stopniu od kosztu tkaniny węglowej użytej do wzmocnienia lekkiej konstrukcji zbiornika.

Wielokrotnie demonstrowan w pojazdach $\mathrm{z}$ ogniwami paliwowymi, zbiorniki wodoru na ciśnienia 350atm i 700atm. Zbiorniki te uzyskały certyfikat ISO 11439 w Unii Europejskiej oraz certyfikaty w USA, Niemczech, Japonii i Islandii. Dostępne na rynku zbiorniki na ciśnienie 700 atm charakteryzują się współczynnikiem bezpieczeństwa 2,35 (ciśnienie rozrywania 1652 atm).

Prowadzone są prace nad ulepszaniem metod magazynowania wodoru idące w kierunku wytwarzania zbiorników kriociśnieniowych. Prace te zostały oparte na założeniu, że przy ustalonym ciśnieniu i objętości pojemność masowa zbiornika zwiększa się wraz ze spadkiem temperatury. Chłodząc zbiornik od temperatury pokojowej do temperatury ciekłego azotu $\left(77 \mathrm{~K}=-196^{\circ} \mathrm{C}\right)$, jego pojemność

\footnotetext{
M. Kulazynski, W. CADEK, Hydrogen storage, www.hyweb.de
}

M. Kulazynski, W. CADEK, Hydrogen storage, www.hyweb.de 
masowa zwiększa się czterokrotnie, przy tym objętość układu zwiększa się znacznie mniej. ${ }^{6}$

Inny kierunek badań obejmuje zbiorniki komfortowe, czyli dopasowane kształtem do gabarytów pojazdu. Jak już zostało wczesnej wspomniano obecnie zbiorniki mają kształt cylindryczny, ich sumaryczna liczba może powodować umieszczenie kabiny pasażerskiej na zbiornikach wodoru, co poza mniejszą pojemnością wnętrza pojazdu ma także aspekt psychologiczny.

Cena zbiornika wodoru o pojemności 150 l na ciśnienie robocze 24,8 MPa pełnokompozytowego oferowanego przez firmy MAN, ALUSUISSE, Diehl, wynosiła $8000 \mathrm{DM}^{7}$

Ciekły wodór także może by magazynowany w odpowiednich zbiornikach. Gęstość energii wodoru ulega zwiększeniu także poprzez skroplenie go. Proces przeprowadzenia wodoru ze stanu gazowego w ciekły wymaga znacznego nakładu energii, podobnie jak utrzymywanie wodoru w stanie ciekłym. Są jednak korzyści z tego płynące jak dużej gęstości, a mianowicie grawimetryczna oraz objętościowa ciekłego wodoru $\left(\mathrm{LH}_{2}\right.$ - „liquid” $\left.\mathrm{H}_{2}\right)$. Jak pokazuje rysunek 2 korzyści te przewyższają znacznie wszystkie inne sposoby magazynowania wodoru.

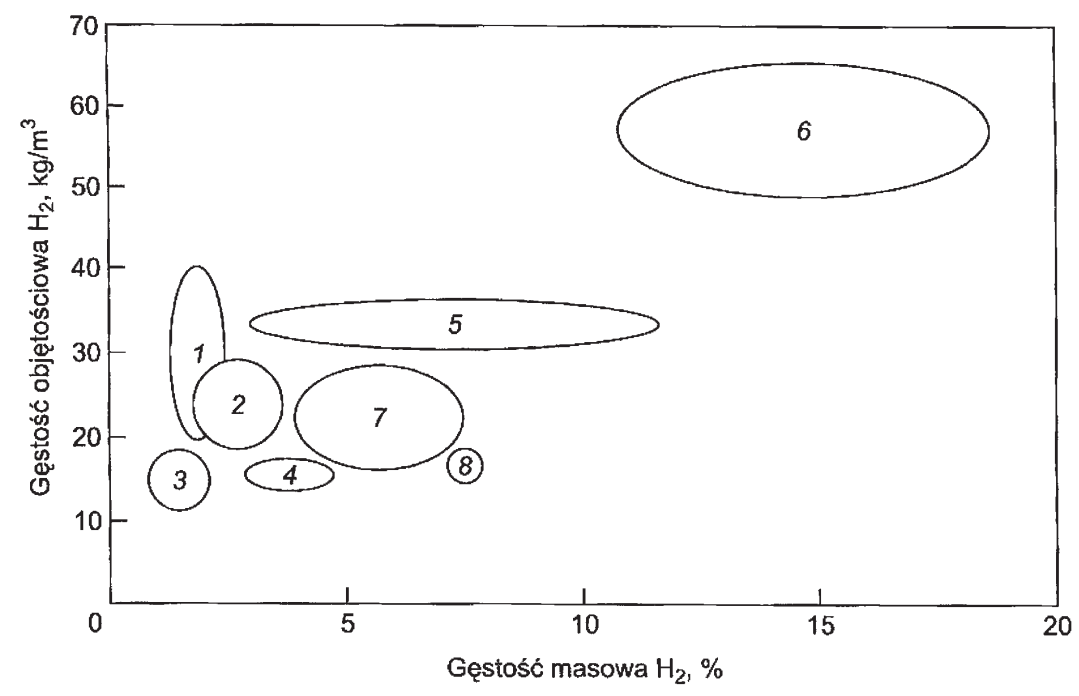

Rys. $2^{8}$ Pojemność magazynowa $H_{2}$ różnych układów

Gdzie: 1-wodorki metali, 2-mikrokulki, 3- $\mathrm{H}_{2}$ sprężony w pojemnikach metalowych, 4- $\mathrm{H}_{4}$ sprężony $w$ pojemnikach kompozytowych, 5- $\mathrm{H}_{2}$ sprężony w warunkach kriogenicznych $(80 \mathrm{~K}), 6-\mathrm{H}_{2}$ ciekły w zbiornikach superzaizolowanych, 7- $\mathrm{H}_{2}$ zaadsorbowany $w$ warunkach kriogenicznych, 8-kulki kompozytowe.

6 N. TAkeichi, H. Senon, Hybrid Hydrogen storage wessel, Hydrogen Energy, 2003, nr 28, s. 1121. M. Kulazynski, W. CADEK, Hydrogen storage, www.hyweb.de

8 N. TAKeichi, H. Senon, Hybrid Hydrogen storage wessel, Hydrogen Energy, 2003, nr 28, s. 1121. 
Skroplenie wodoru wymaga dużych nakładów energii jest to zwykle około $30 \ldots 40 \%$ wartości energetycznej wodoru sprężonego. Koszty magazynowania wodoru w stanie ciekłym zależą od objętości zbiornika, masy, kosztu zbiornika oraz rodzaju materiałów izolacyjnych. Zbiorniki ciekłego wodoru posiadając muszą oprzyrządowane w które nie są wyposażone inne rodzaje zbiorników. Mają kształt cylindryczny o dość dużym stosunku średnicy do długości. Zbudowane są z dwóch naczyń, zewnętrznego i wewnętrznego miedzy którymi jest warstwa superizolacji. Zwykle wyposażone są we wskaźnik poziomu, zawór odcinający podgrzewacz elektryczny, chłodnicę wodną, zawór zwrotny, zawór na linii doprowadzającej wodór oraz linię wyprowadzania cieczy i wyprowadzania gazu. Omówiony schemat zbiornika wodoru ciekłego został umieszczony na rysunku 9.

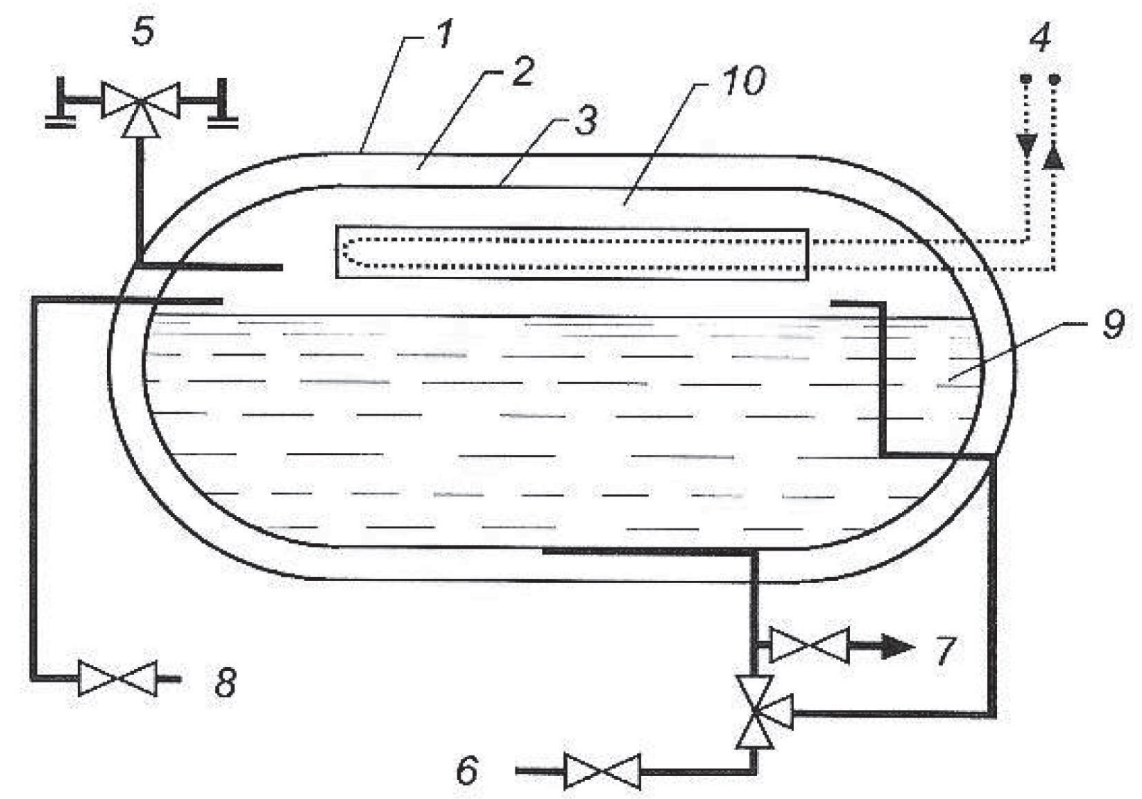

Rys. $9^{9}$ Schemat stacjonarnego zbiornika wodoru ciekłego

1-zbiornik zewnętrzny, 2-superizolacja, 3-zbiornik wewnętrzny, 4-chłodnica, 5-linia bezpieczeństwa, 6-linia napetniania, 7-pobór $\mathrm{LH}_{2}$, 8-linia bilansowania gazu, $9-\mathrm{LH}_{2}, 10-\mathrm{GH}_{2}$ („gaseus" $\mathrm{H}_{2}$ )

Badania wykazały, że zbiornik wodoru ciekłego może zmagazynować więcej $\mathrm{H}_{2} \mathrm{w}$ danej objętości niż zbiornik ze sprężonym wodorem. Dla porównania objętościowa pojemność ciekłego wodoru wynosi $0,07 \mathrm{~kg} / \mathrm{dm}^{3}$, a sprężonego pod ciśnieniem $700 \mathrm{~atm}, 0,03 \mathrm{~kg} / \mathrm{dm}^{3}$.

9 J. SurygaŁa, Wodór jako paliwo, WNT, Warszawa 2008, s. 83. 
Ciekły wodór od wytwórcy do dystrybutora transportowany jest przy użyciu ciężarówek o masie $40 \mathrm{t}$, w których mieści się $3370 \mathrm{~kg} \mathrm{~L} \mathrm{H}$. Docelowo jest on magazynowany w zbiornikach stacjonarnych. Największe takie zbiorniki znajdują się na przylądku Cape Canaveral, są własnością NASA, mają one pojemność blisko $3800 \mathrm{~m}^{3}\left(270 \mathrm{t} \mathrm{LH}{ }_{2}\right.$ ), są kształtu sferycznego o średnicy zewnętrznej 20 m. Ze względu na bardzo dobrą izolację tych zbiorników odparowanie dzienne wodoru nie przekracza $0,03 \%$.

Magazynowanie wodoru w formie cieczy może być tańsze niż pod ciśnieniem przy odpowiednio dużej pojemności. Magazynowanie w pojemnikach do 1001 jest drogie, gdyż wymaga superizolacji i ciągłego chłodzenia gazu chłodzącego. Współczynnik odparowania dziennego próżniowo superizolowanych zbiorników wynosi około $0,4 \%$. Większe zbiorniki z próżniowo proszkową izolacją wykazują straty dzienne na poziomie $1 . . .2 \%$.

Popularne są obecnie zbiorniki stacjonarne o pojemności od 1500 (ok. $\left.1100 \mathrm{Nm}^{3}\right)$ do $750001\left(50000 \mathrm{Nm}^{3}\right)$ mają średnicę 1,4...3,8 m i długość $3 . .14$ m. Zbiorniki takie oferowane są przez firmy Linde, Air Liquide i Messner Griesheim.

Na rynku dostępne są także zbiorniki mobilne zainstalowane w samochodach BMW i autobusach MAN-bus SL 202. Zbiornik autobusowy jest złożony z trzech eliptycznych zbiorników międzysekcyjnych, każdy o pojemności 190 l, co odpowiada energii $450 \mathrm{kWh}$. Uzyskiwana jest energia o gęstości 4,5 kWh/kg lub $2,13 \mathrm{kWh} / \mathrm{kg}$. Zbiorniki te posiadają izolację z 200...300 warstw folii, gwarantującą współczynnik dziennych strat paliwa na poziomie nie większym niż $1 \%$. Mimo bardzo dobrej izolacji ciecz kriogeniczna ciągle wrze i odparowuje i dotychczas nie udało się temu zapobiec. Schemat mobilnego zbiornika oferowanego miedzy innymi przez firmę Linde przedstawia rysunek 3. 


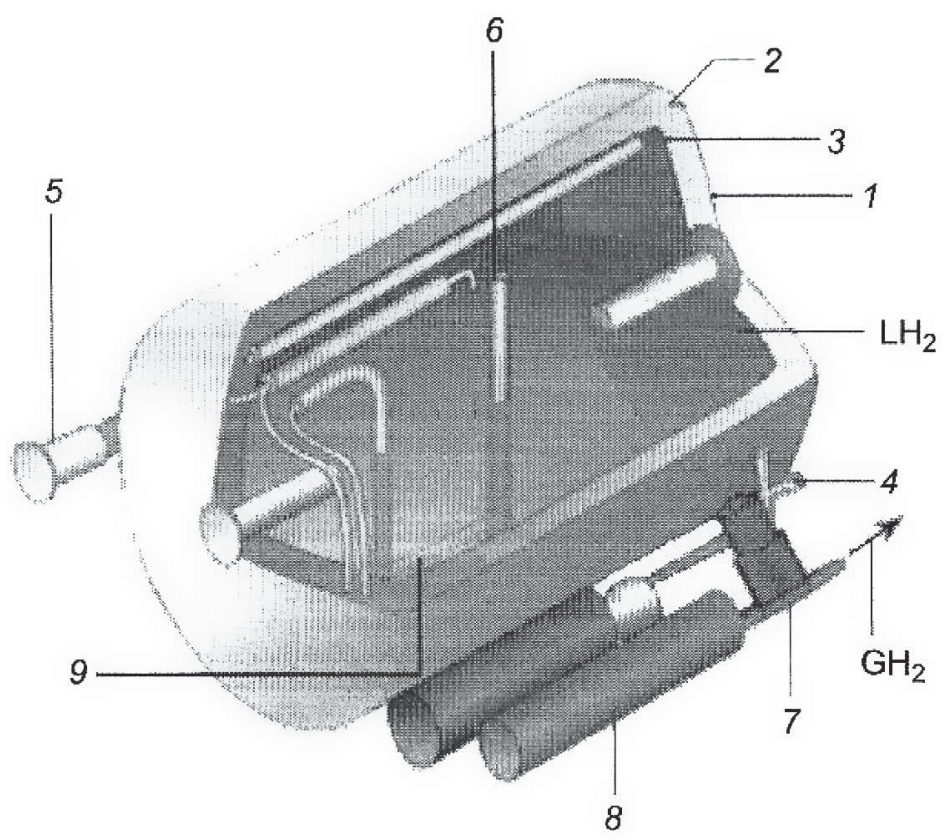

Rys. $3^{10}$ Schemat mobilnego zbiornika wodoru ciektego

1-zbiornik zewnętrzny, 2-superizolacja, 3-zbiornik wewnętrzny, 4-zawór bezpieczeństwa, 5-linia bezpieczeństwa, 6-wskaźnik poziomu cieczy, 7-zawór odcinający, 8-chłodnica, 9 - grzejnik elektryczny

Zbiorniki hybrydowe z wodorem kriosprężonym (zaizolowane naczynia ciśnieniowe) są lżejsze niż pojemniki z wodorkami i charakteryzują się bardziej zagęszczoną energią $\mathrm{w}$ porównaniu z naczyniami ciśnieniowymi w temperaturze pokojowej. Nie wymagają tak niskiej temperatury jak w przypadku ciekłego wodoru, zatem zapotrzebowanie na skroplenie i utrzymanie wodoru w stanie płynnym jest mniejsze. ${ }^{11}$ Także straty odparowania są mniejsze.

Wodorki to związki wodoru z innymi pierwiastkami. Najczęściej wodorkami określa się związki wszystkich metali, ich stopów i ich związków miedzy metalicznych z wodorem oraz wodorki kompleksowe. W tej grupie charakter metaliczny wykazują wodorki metali przejściowych, itru i lantanowców.

Charakterystyczne jest też, że stopy i związki międzymetaliczne zawierające pierwiastek dobrze pochłaniający wodór, również są dobrymi absorbentami

10 S. Satyapal, J. Petrovic, Wodór w baku, Świat nauki, 2007, nr 5, s. 46.

11 S. M. Aceves, J. Martinez-Frias, O. Garcia-Villazana, Analytical and experimental evaluation of insulated pressure vessels of cryogenic hydrogen storage, Hydrogen Energy 2000, nr 25, s 2075 
wodoru. Dlatego związki ziem rzadkich i itru z metalami przejściowymi łatwo pochłaniają wodór, czego przykładem jest $\mathrm{LaNi}_{5}$ powszechnie obecnie stosowany do magazynowania wodoru na skalę laboratoryjną oraz jako elektrody baterii wodorowych.

Wodorek metalu może być uzyskany w wyniku następujących reakcji:

- Reakcji chemisorpcji wodoru $\mathrm{z}$ fazy gazowej:

gdzie:

$$
\mathbf{M}+\mathbf{x} / 2 \mathbf{H}_{2} \Leftrightarrow \mathbf{M H}_{\mathrm{x}}(1)
$$

$\mathrm{MH}_{\mathrm{x}}$ - wodorek metalu

$\mathrm{x}$ - ilość składowanego wodoru

- Reakcji elektrochemicznej:

a) w środowisku kwaśnym:

$$
\mathbf{M}+\mathbf{x H}++\mathbf{x e} \Leftrightarrow \mathbf{M H}_{\mathrm{x}}(2 \mathrm{a})
$$

b) w środowisku alkaicznym:

$$
\mathrm{M}+\mathrm{xH}_{2} \mathrm{O}+\mathrm{xe}-\Leftrightarrow \mathrm{MH}_{\mathrm{x}}+\mathrm{xOH}(2 \mathrm{~b})
$$

$\mathrm{W}$ wodorkach metali wodór może by magazynowany i uwalniany w niskiej temperaturze i niskim ciśnieniu. Wodór może być magazynowany na powierzchni ciał stałych (adsorpcja) lub wewnątrz nich (absorpcja).W adsorpcji wodór może być magazynowany w formie atomowej lub cząsteczkowej, w absorpcji natomiast cząsteczki wodoru są zdysocjowane na atomy i w takiej formie są przyłączane do sieci krystalicznej. Na rys. 4a przedstawiono adsorpcję wodoru na węglu aktywnym, rys. $4 \mathrm{~b}$ natomiast obrazuje adsorpcję tego pierwiastka $\mathrm{w}$ sieci krystalicznej metalu.

a)

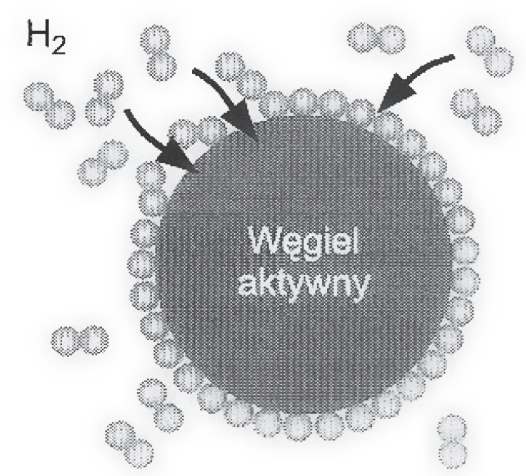

b)

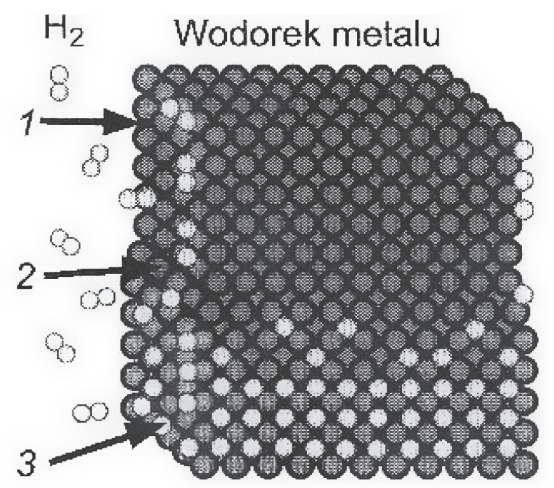

Rys. $4^{12}$ Adsorpcja wodoru na weglu aktywnym (a), absorpcja wodoru w metalu (b) 1-czasteczki $\mathrm{H}_{2}$ zaadsorbowane na metalu, 2-wodór w formie roztworu stałego,3-atomy wodoru w węzłach sieci krystalicznej metalu

\footnotetext{
12 J. SuRYgaŁA, Wodór jako paliwo, WNT, Warszawa 2008, s. 85.
} 
Według przeprowadzonych badań istnieje osiem rodzajów wodorków, są to typy $\mathrm{AB}_{2}, \mathrm{AB}, \mathrm{A}_{2} \mathrm{~B}$, związki kompleksowe, stopy glinu, połączenia międzymetaliczne i roztwory stałe. ${ }^{13}$

Absorpcja wodoru do wnętrza metalu jest uzależniona od energii cząsteczki. ${ }^{14} \mathrm{~W}$ przypadku magnezu dla małych energii $(\mathrm{E}<0,4 \mathrm{eV})$ cząsteczka wodoru może ulec na powierzchni metalu tylko fizyko-absorpcji za co odpowiedzialne są siły van der Waalsa. Cząsteczki wodoru są wtedy słabo związane z powierzchnia metalu. Dla wyższych energii (E $>0,4 \mathrm{eV})$ cząsteczka wodoru może ulec chemisorpcji. Tworząc monowarstwę wodoru na powierzchni metalu silnie związaną kowalencyjnym wiązaniem, by atom wodoru mógł dyfundować do wnętrza metalu, musi pokonać dodatkowo barierę energetyczna $(\mathrm{E}=0,1 \mathrm{eV})$. W przypadku chemisorpcji reakcja ma charakter egzotermiczny.

W celu uwolnienia wodoru (desorpcji) należy wiec podgrzać wodorek do odpowiedniej temperatury i obniżyć ciśnienie. Pojemność materiału oraz jego zdolność do absorpcji lub desorpcji określają izotermy absorpcji-desorpcji zwane „krzywymi p-c-T” („pressure-composition-temperature”). Jak można zaobserwować na wykresie przedstawionym na rys. 12, wraz ze wzrostem ciśnienia następuje szybki przyrost zaabsorbowanego wodoru i powstaje nienasycony jednofazowy wodorek (faza $\alpha$ ). Następnie, gdy osiągnięte zostanie odpowiednio duże ciśnienie następuje szybka dyfuzja wodoru do wnętrza próbki co na krzywej p-c-T jest obserwowane jako przyrost koncentracji wodoru w próbce przy niewiele zmieniającym się ciśnieniu (plateau). Pojawienie się „plateau” na krzywej p-c-T jest charakterystyczne dla materiałów absorbujących wodór. Gdy próbka zostanie nasycona wodorem (faza $\beta$ ) więcej wodoru nie przyjmie i wówczas obserwuje się szybki wzrost ciśnienia i osiągniecie maksymalnej pojemności gromadzonego wodoru. Desorpcja, jak widać $\mathrm{z}$ wykresu, musi odbywać się pod niższymi ciśnieniem, tak wiec musi powstać histereza.

\footnotetext{
hydropark.ca.sandia.gov

14 R.B. Schwarz, Critical Parameters in the Performance of the Hydrogen Storage aterial. Los Alamos National Laboratory, 1997, http://itri.loyola.edu/nano/us_r_n_d/04_06.htm
} 


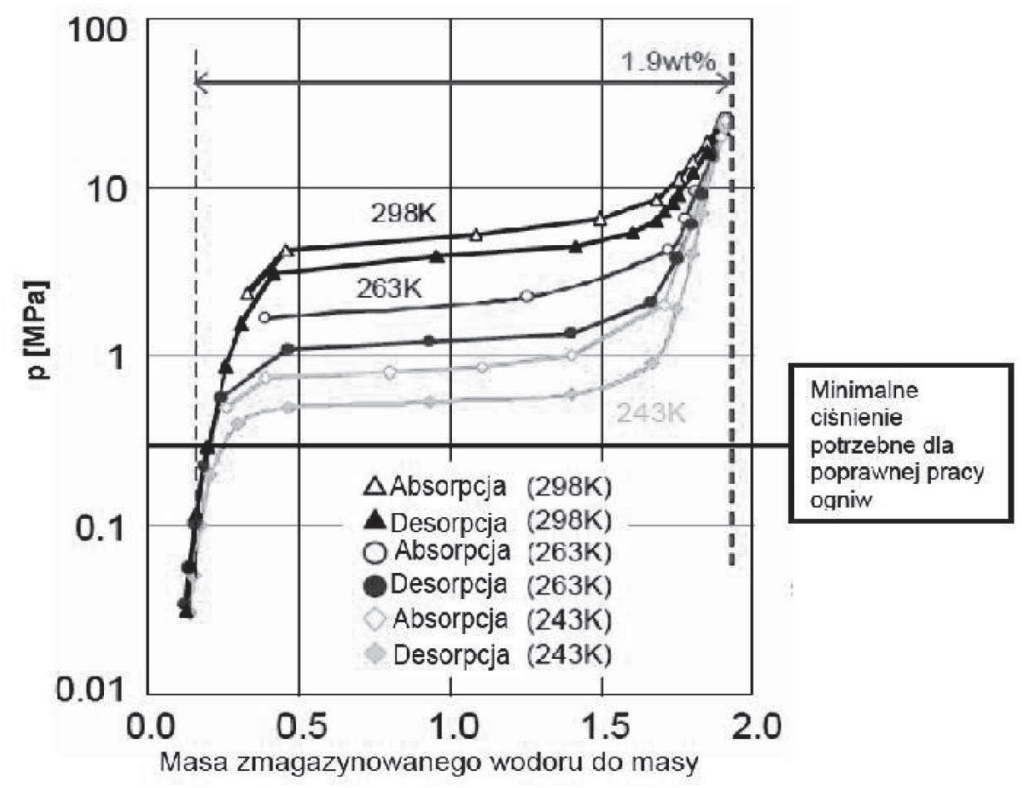

Rys. $5^{15}$ Wykres p-c-T dla stopu Ti-Cr-Mn

Wodorki metalu można podzielić na niskotemperaturowe i wysokotemperaturowe. Niektóre metale, jak np.: pallad, bardzo łatwo pochłaniają wodór przy niewielkich ciśnieniach i temperaturach bliskich temperaturze pokojowej. Tego typu wodorki są zaliczane do grupy wodorków niskotemperaturowych. Inne metale lub stopy metali musza zostać podgrzane do wysokich temperatur by uzyskać zdolność do pochłaniania wodoru. Tego typu materiały to grupa wodorków wysokotemperaturowych.

Do zalet tego sposobu magazynowania wodoru można zaliczy niskie ciśnienie utrzymywane na stałym poziomie prawie przez cały czas pracy wodorku co pokazano na rys. 6.

15 E. Aкiba, Japan's Global Vision for Hydrogen Storage Technology and the Hydrogen Economy, Gordon Research Conference, Hydrogen - metal Systems 14 July 2005. 


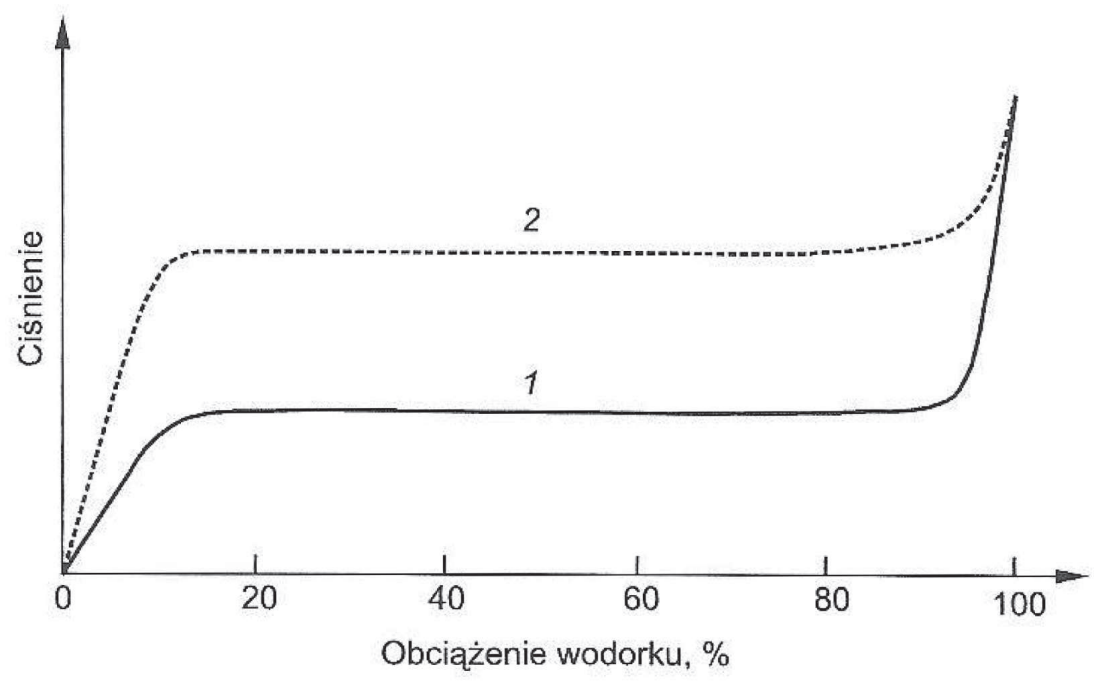

Rys. $6{ }^{16}$ Magazynowanie wodoru $w$ wodorkach metali

1-krzywa nasycenia $\mathrm{H}_{2}(\mathrm{~T}<, \mathrm{p}<), 2$-krzywa sczerpywania $\mathrm{H}_{2}(\mathrm{~T}>, \mathrm{p}>)$

Ciśnienie to zawiera się w przedziale od $0,25 \ldots 10 \mathrm{MPa}$ a objętość magazynowania jest duża i wynosi $0,21 \ldots 0,39 \mathrm{kWh} / \mathrm{kg}$ lub $1,0 \ldots 1,5 \mathrm{kWh} / \mathrm{l}$. Wodorki oferowane są przez niemiecką firmę Gesellschaft fur Elektrometalurgie ( GfE), jak również w Japonii i Kanadzie. Koszty wodorków zależą od temperatury i ciśnienia roboczego oraz gęstości i rozmiarów ładunku.

W przyszłości przewiduje się rozwój innych aspektów wykorzystania wodorków metali, inne ich rodzaje, zakres pracy przy kilkakrotnie większych pojemnościach. Rodzaj wodorku jaki może by stosowany jest zależny od rodzaju stosowanego ogniwa paliwowego, w przypadku tego typu rodzajów nośników energii oraz miejsca i warunków pracy ogniwa. Cechy, które określają wodorki jako dobre zbiorniki wodoru to:

- zdolność do odwracalnego magazynowania wodoru,

- duża pojemność magazynowanego wodoru,

- niskie ciśnienie i temperatura $\left(\mathrm{do} \sim 90^{\circ} \mathrm{C}\right)$ dysocjacji wodorku,

- duża szybkość absorpcji i desorpcji,

- mała ilość energii wymaganej do uwolnienia wodoru,

- mała wrażliwość na zanieczyszczenia gazowe,

- duża ilość możliwych cykli ładowania rozładowania,

- bezpieczeństwo (niskie ciśnienie, niepalność),

- niska cena.

16 J. Suryga£a, Wodór jako paliwo, WNT, Warszawa 2008, s. 89. 
Optymalny poziom ciśnienie-temperatura dla pojazdów wyposażonych $\mathrm{w}$ ogniwo paliwowe PEMFC to $1 \ldots 10$ atm i $25 \ldots 120^{\circ} \mathrm{C}$. Stosowane jest ciepło zrzutowe $\mathrm{z}$ ogniwa paliwowego $\mathrm{w}$ celu uwolnienia wodoru z wodorku. Uzyskana obecnie temperatura w wyniku wykorzystania ciepła zrzutowego wynosi $80^{\circ} \mathrm{C}$. Stosowanie wyższej temperatury desorpcji wymaga opracowania membran wysokotemperaturowych. ${ }^{17}$

Proste wodorki metalu, do których należy $\mathrm{LaNi}_{5} \mathrm{H}_{6}$ przyłączające wodór do swej struktury krystalograficznej, mogą funkcjonować w wyżej wymienionym zakresie temperatur, ale ich pojemność masowa jest zbyt mała (ok. 1,3\% m/m), a cena zbyt wysoka. Większe potencjały pojemności w oknie aktywności mają kompleksowe wodorki metali, jak np. połączenia typu alanatów $\left(\mathrm{AlH}_{4}\right)^{18}$. Związki te mogą magazynować i uwalniać wodór w sposób odwracalny, w obecności katalizatorów promotowanych tytanem ze względu na następczą dwustopniową reakcję alanatu sodu, reakcje (3) i (4).

$$
\begin{aligned}
& \mathrm{NaAlH}_{4} \leftrightarrow \frac{1}{3} \mathrm{Na}_{3} \mathrm{AlH}_{6}+\frac{2}{3} \mathrm{Al}+\mathrm{H}_{2} \\
& \mathrm{NaAlH}_{6} \leftrightarrow 3 \mathrm{NaH}+\frac{3}{2} \mathrm{H}_{2}
\end{aligned}
$$

Reakcja (3) pod ciśnieniem 1 atm jest termodynamicznie uprzywilejowana $\mathrm{w}$ temperaturze $33^{\circ} \mathrm{C}$ i w wyniku jej przebiegu uwalnia się $3,7 \% \mathrm{~m} / \mathrm{m} \mathrm{H}_{2}$, natomiast reakcja (4) zachodzi w temperaturze $110^{\circ} \mathrm{C}$ i uwalnia się $1,8 \% \mathrm{~m} / \mathrm{m} \mathrm{H}_{2}$. Parametrem kluczowym jest ilość wodoru jaką materiał może uwolnić w warunkach pracy, a nie pojemność sorpcyjna. Cechy kompleksowych wodorków metali takie jak:

- mała pojemność $\mathrm{H}_{2}$

- wolne ładowanie i uwalnianie

- wysoka cena,

- dyskwalifikują je z zastosowań w pojazdach samochodowych.

Pojemność maksymalna występuje w przypadku alanatu sodu i wynosi 5,5\% $\mathrm{m} / \mathrm{m}$. W układzie opartym na amidzie Li, opracowanym niedawno $\mathrm{w}$ temperaturze $285^{\circ} \mathrm{C}$ i pod ciśnieniem 1 atm zachodzi reakcja (5):

$$
\mathrm{LiNa}+\mathrm{H}_{2} \leftrightarrow \mathrm{LiNH}_{2}+\mathrm{LiH}
$$

\footnotetext{
17 J. SurygaŁA, Wodór jako paliwo, WNT, Warszawa 2008, s. 89.

18 www1.eere.energy.gov.
} 
$\mathrm{W}$ wyniku tej reakcji można w sposób odwracalny magazynować 6,5\% $(\mathrm{m} / \mathrm{m})$ wodoru. Zbyt wysoką temperaturę poza obszarem pracy można obniżyć przez modyfikację przebiegu reakcji związkami magnezu.

Chemiczne magazynowanie wodoru to technologia, której wodór wytwarzany jest w reakcji chemicznej. Na przykład podczas działania wodą lub alkoholem na połączenia zawierające wodór. Tego typu reakcje zwykle nie są odwracalne w pojeździe samochodowym, dlatego też „zużyte” paliwo lub/i produkt uboczny należy usuwać $\mathrm{z}$ pojazdu i regenerować na stacji paliw. ${ }^{19}$

Materiałami ulegającymi omawianym reakcjom są wodorki metali lekkich. W tych związkach wodór występuje na ujemnym (-1) stopniu utlenienia, wodór wydzielany jest $\mathrm{w}$ reakcji ze związkiem, gdzie pierwiastek ten występuję na dodatnim (+1) stopniu utlenienia (np. $\mathrm{H}_{2} \mathrm{ONH}_{3}, \mathrm{H}_{2} \mathrm{~S}$ ). Zastosowanie tego typu układu do celów praktycznych wymaga spełnienia następujących warunków:

- układ powinie być termodynamicznie samorzutny $(\Delta \mathrm{G}>0)$, kinetycznie sterowalny,

- stosowane reagenty proste i dostępne,

- wytwarzany wodór powinien spełniać wymagania ogniw PEMFC,

- układ powinien by kompatybilny ze wszystkimi metodami magazynowania wodoru, dostarczając wodór do ogniwa paliwowego gdy jest potrzebny. ${ }^{20}$

Hydroliza wodorków jako reakcja wytwarzania wodoru, to reakcja samorzutna, egzotermiczna i nieodwracalna. W tabeli 1 zostały podane przykłady takich nieodwracalnych reakcji, jednak niektóre wodorki kompleksowe wykazują odwracalność w obecności katalizatorów tytanowych. ${ }^{21}$ Istotny jest tu fakt, że dekompozycja $\mathrm{NaAlH}_{4}$ zachodzi w dwóch etapach, reakcje (6) i (7):

$$
\begin{aligned}
& 3 \mathrm{NaAlH}_{4} \stackrel{120^{\circ} \mathrm{C}}{\longrightarrow} \mathrm{Na}_{3} \mathrm{AlH}_{6}+3 \mathrm{H}_{2}+2 \mathrm{Al} \\
& \mathrm{Na}_{3} \mathrm{AlH}_{6} \stackrel{250^{\circ} \mathrm{C}}{\longrightarrow} 3 \mathrm{NaH}+\frac{3}{2} \mathrm{H}_{2}+\mathrm{Al}
\end{aligned}
$$

19 J. SuRYgaŁA, Wodór jako paliwo, WNT, Warszawa 2008, s. 91.

20 Hydrogen Storage Materiale Work Shop Proceedings, Argome National Laboratory, Argonne, IL, 2002, USA.

21 E. Fakioglu, Y. Yurum, T. N. Veziroglu, A review of Hydrogen storage systems based on boron and its compounds, Hydrogen Energy, 2004, nr 29, s. 193. 
Tabela $1 .{ }^{22}$ Przykłady wytwarzania wodoru przez hydrolize wodorków

\begin{tabular}{|c|c|c|}
\hline \multirow{2}{*}{ Reakcja } & \multicolumn{2}{|c|}{ Wydajność $\mathrm{H}_{2}$} \\
\hline & $\% \mathrm{~m} / \mathrm{m}$ & $\mathrm{kWh} / \mathrm{kg}$ \\
\hline $\mathrm{LiH}+\mathrm{H}_{2} \mathrm{O} \rightarrow \mathrm{LiOH}+\mathrm{H}_{2}$ & 7,7 & 1,46 \\
\hline $\mathrm{NaH}+\mathrm{H}_{2} \mathrm{O} \rightarrow \mathrm{NaOH}+\mathrm{H}_{2}$ & 4,8 & 0,91 \\
\hline $\mathrm{CaH}_{2}+2 \mathrm{H}_{2} \mathrm{O} \rightarrow \mathrm{Ca}(\mathrm{OH})_{2}+2 \mathrm{H}_{2}$ & 5,2 & 0,99 \\
\hline $\mathrm{LiAlH}_{4}+4 \mathrm{H}_{2} \mathrm{O} \rightarrow \mathrm{LiOH}+\mathrm{Al}(\mathrm{OH})_{3}+4 \mathrm{H}_{2}$ & 7,3 & 1,38 \\
\hline $\mathrm{LiBH}_{4}+4 \mathrm{H}_{2} \mathrm{O} \rightarrow \mathrm{LiOH}+\mathrm{H}_{3} \mathrm{BO}_{3}+4 \mathrm{H}_{2}$ & 8,6 & 1,63 \\
\hline $\mathrm{NaAlH}_{4}+4 \mathrm{H}_{2} \mathrm{O} \rightarrow \mathrm{NaOH}+\mathrm{Al}(\mathrm{OH})_{3}+4 \mathrm{H}_{2}$ & 6,4 & 1,21 \\
\hline $\mathrm{NaBH}_{4}+4 \mathrm{H}_{2} \mathrm{O} \rightarrow \mathrm{NaOH}+\mathrm{H}_{3} \mathrm{BO}_{3}+4 \mathrm{H}_{2}$ & 7,3 & 1,38 \\
\hline
\end{tabular}

Natomiast reakcja regeneracji (8), zachodzi w temperaturze $104^{\circ} \mathrm{C}$, pod ciśnieniem $\mathrm{H}_{2} 87$ atm w czasie $17 \mathrm{~h}$.

$$
\mathrm{NH}+\frac{3}{2} \mathrm{H}_{2}+\mathrm{Al} \rightarrow \mathrm{NaAlH}_{4}
$$

W tych warunkach można odwracalnie zmagazynować $5,43 \% \mathrm{~m} / \mathrm{m}$ wodoru. Alanat $\mathrm{LiAlH}_{4}$ zawierający $10,5 \% \mathrm{~m} / \mathrm{m}$ wodoru może ulega rozkładowi w dwóch reakcjach (9) i (10), w temperaturach 160 i $200{ }^{\circ} \mathrm{C}$, uwalniając 7,89\% $\mathrm{m} / \mathrm{m} \mathrm{H}_{2}$.

$$
\begin{aligned}
& 3 \mathrm{LiAlH}_{4} \stackrel{160^{\circ} \mathrm{C}}{\longrightarrow} \mathrm{Li}_{3} \mathrm{AlH}_{6}+3 \mathrm{H}_{2}+3 \mathrm{Al} \\
& \mathrm{Li}_{3} \mathrm{AlH}_{6} \stackrel{200^{\circ} \mathrm{C}}{\longrightarrow} 3 \mathrm{LiH}+\frac{3}{2} \mathrm{H}_{2}+\mathrm{Al}
\end{aligned}
$$

Materiał ten jest regenerowany przez uwodornienie przy ciśnieniu $60 \ldots 150$ atm. Warunek ten wyklucza $\mathrm{LiAlH}_{4}$ jako materiał w odwracalnych procesach magazynowania $\mathrm{H}_{2}$.

$\mathrm{Z}$ kolei wodorek litu $(\mathrm{LiH})$ zawierający $13 \% \mathrm{H}_{2}$ ulega dekompozycji terminowej w temperaturze $825^{\circ} \mathrm{C}$ i jest regenerowany wodą $\mathrm{w}$ temperaturze $350^{\circ} \mathrm{C}$, reakcje (11) i (12):

$$
\begin{array}{ll}
\text { Piroliza: } & 2 \mathrm{LiH} \stackrel{825^{\circ} \mathrm{C}}{\longrightarrow} \mathrm{H}_{2}+2 \mathrm{Li} \\
\text { Regeneracja: } & 2 \mathrm{Li}+\mathrm{H}_{2} \mathrm{O} \stackrel{350^{\circ} \mathrm{C}}{\longrightarrow} 2 \mathrm{LiH}+\frac{1}{2} \mathrm{O}_{2}
\end{array}
$$

Poza wodorkami metali lekkich duże znaczenie jako połączenia magazynujące wodór mają borowodorki. Tabela 2 pokazuje zawartość wodoru w niektórych borowodorkach.

22 Hydrogen Storage Materiale Work Shop Proceedings, Argome National Laboratory, Argonne, IL, 2002, USA. 
Sylwia Gołębiowska i Krzysztof Biernat

Tabela 2. ${ }^{23}$ Zawartość wodoru w niektórych borowodorkach

\begin{tabular}{|l|c|}
\hline \multicolumn{1}{|c|}{ Wodorek } & Zawartość $\mathrm{H}_{2,} \%$ m/m (ze wzoru) \\
\hline $\mathrm{NaBH}_{4}$ & 10,6 \\
$\mathrm{Al}\left(\mathrm{BH}_{4}\right)_{3}$ & 16,8 \\
$\mathrm{LiAlH}$ & $\left(\mathrm{BH}_{4}\right)_{2}$ \\
$\mathrm{Mg}\left(\mathrm{BH}_{4}\right)_{2}$ & 15,2 \\
$\mathrm{Ca}\left(\mathrm{BH}_{4}\right)_{2}$ & 14,8 \\
$\mathrm{Ti}\left(\mathrm{BH}_{4}\right)_{3}$ & 11,5 \\
$\mathrm{Zr}\left(\mathrm{BH}_{4}\right)_{3}$ & 13,0 \\
$\mathrm{Fe}\left(\mathrm{BH}_{4}\right)_{3}$ & 8,8 \\
\hline
\end{tabular}

W tej grupie materiałów jako potencjalne zbiorniki wodoru mogą być $\mathrm{LiBH}_{4}$ i $\mathrm{NaBH}_{4}$. Badania przeprowadzone w latach 1998-1999 wykazały przydatność tych materiałów do magazynowania wodoru dla ogniw alkalicznych. Firma Millennium Cell skomercjalizowała $\mathrm{NaBH}_{4}$. Kontrolowana egzotermiczna reakcja $\mathrm{NaBH}_{4} \mathrm{i}_{2} \mathrm{O}$, zachodząca bezciśnieniowo w temperaturze pokojowej, bez reakcji ubocznych i niebezpiecznych produktów prowadzi do wytworzenia wodoru. Przebieg reakcji ilustrują równania (13) i (14):

$$
\begin{array}{ll}
\text { Hydroliza: } & \mathrm{NaBH}_{4}+2 \mathrm{H}_{2} \mathrm{O} \longrightarrow \mathrm{NaBO}_{2}+4 \mathrm{H}_{2} \\
\text { Regeneracja: } & \mathrm{NaBH}\left(\mathrm{OMe}_{3}\right)+\mathrm{BH}_{3} \longrightarrow \mathrm{NaBH}_{4}+\mathrm{B}(\mathrm{OMe})_{3}
\end{array}
$$

Reakcja hydrolizy uwalnia $10,6 \%(\mathrm{~m} / \mathrm{m}) \mathrm{H}_{2}$.

$\mathrm{Na}$ podstawie badań stwierdzono, że borowodorek sodu ma największe szanse komercjalizacji. ${ }^{24}$ Odwracalne reakcje magazynowania i uwalniania $\mathrm{H}_{2}$ ze związku niskocząsteczkowego przebiegają w przypadku tych materiałów w łagodnych warunkach. Ostatnio przeprowadzone analizy pokazały, że uwalnianie $\mathrm{H}_{2}$ zachodzi znacznie łatwiej w obecności katalizatora, a proces może by przeprowadzony autotermicznie z konwersją większa niż 95\%. ${ }^{25}$

Nowy materiał sorbujący wodór może stanowić węgiel elementarny ze względu na niski koszt oraz niższą masę atomową w porównaniu z metalami. Zainteresowanie materiałami węglowymi jako magazynami wodoru spowodowało odkrycie nowych nanostruktur, takich jak fulereny, nanorurki i nanowłók-

23 J. SuRYgaŁa, Wodór jako paliwo, WNT, Warszawa 2008, s. 93.

24 J. SuRYgaŁA, Wodór jako paliwo, WNT, Warszawa 2008, s. 93.

25 Q. Zhang, G. Smith, Y. WU, Catalytic hydrolysis of sodium borohydridein autu-thermal fixedbed reactor, Hydrogen Energy, 2006, nr 31, s. 961. 
na węglowe ${ }^{26}$. Pod pojeciem „ materiałów węglowych" rozumie się także węgle aktywne i aerożele.

Fulereny ${ }^{27}$ są alotropową odmianą węgla. Fulereny zawierające 60 atomów węgla i więcej są podatne na przyłączanie wodoru ${ }^{28}$. Ze względu na niższe ciepło tworzenia uwodorniona cząsteczka fulerenowa jest stabilniejsza niż płaska cząsteczka $\mathrm{C}_{60}$. Efektywność energetyczna uwodornionego fulerenu $\mathrm{C}_{60} \mathrm{w}$ porównaniu do efektywności wodorków metali jest pięciokrotnie wyższa. $(15)^{29}$ :

Fuleren $\mathrm{C}_{60}$ może być uwodorniony elektrochemicznie zgodnie z reakcją

$$
\mathrm{C}_{60}+x \mathrm{H}_{2} \mathrm{O}+x e^{-}=\mathrm{C}_{60} \mathrm{H}_{x}+x \mathrm{OH}^{-}
$$

Dla $\mathrm{x}=60$ pojemność elektrochemiczna układu przewyższa sześciokrotnie wartość odpowiadającą najlepszym wodorkom metali.

Fulereny mogą być także uwodornione chemicznie. Proces ten może przebiegać w reakcji Bircha, która polega na redukcji związków organicznych za pomocą litowców (litu, sodu) w ciekłym amoniaku lub aminach alifatycznych.

Wśród wymienionych materiałów węglowych największym zainteresowaniem cieszą się ostatnio nanorurki. Jedną z możliwości zastosowania nanorurek węglowych jest aplikacja ich jako najmniejszych na świecie butli gazowych. Wodór absorbowany w tych materiałach może kondensować wewnątrz nanorurek lub tworzyć warstwę w ich strukturze. Na podstawie tej wiedzy może by oszacowana potencjał absorpcyjny i pojemność nanorurek..$^{30}$ Ilość zgromadzonego wodoru zależy liniowo od średnicy nanorurek, dla większych niż 0,671 nm wynosi $1,5 \%(\mathrm{~m} / \mathrm{m})$. W warstwie monomolekularnej zachodzi absorpcja powierzchniowa wykazująca maksymalna pojemność sorpcyjną 3,3\% $(\mathrm{m} / \mathrm{m}) . \mathrm{Na}$ podstawie badań stwierdzono, że w temperaturze pokojowej odwracalna pojemność sorpcyjna wynosi $1,5 \%(\mathrm{~m} / \mathrm{m})$.

Na zwiększenie możliwości sorpcji wodoru w nanorurkach zdecydowany wpływ ma obniżenie temperatury i podwyższenie ciśnienia. Badania przeprowadzone przez Darkrima wykazały, że nanorurki o średnicy 2,2 nm w temperaturze $77 \mathrm{~K}$ i pod ciśnieniem 10MPa maja pojemność absorpcyjną $11,24 \%(\mathrm{~m} / \mathrm{m})$, co

\footnotetext{
26 A. Huczko, Magazynowanie wodoru w fulerenach i nanorurkach weglowych, Przemysł Chemiczny 2002, 81, nr 1.

27 http://pl.wikipedia.org.

28 A. Huczko, Magazynowanie wodoru w fulerenach i nanorurkach weglowych, Przemysł Chemiczny 2002, 81, nr 1 .

29 A. Huczko, Magazynowanie wodoru w fulerenach i nanorurkach weglowych, Przemysł Chemiczny 2002, 81, nr 1, s. 200.

30 A. Zuttel, P. Suolan, Hydrogen storage in karbon nanostructures, Hydrogen Energy, 2002, nr 27, s. 203.
} 
dało stosunek atomowy $\mathrm{H} / \mathrm{C}=2 .{ }^{31}$ Gęstość objętościowa w tych warunkach termodynamicznych wynosi $60 \mathrm{~kg} / \mathrm{m}^{3}$. Aby spełniać wymogi $\mathrm{DOE}^{32}$ dla materiałów do odwracalnej sorpcji wodoru, nanorurki musza się charakteryzować się sorpcją $6,25(\mathrm{~m} / \mathrm{m})$ oraz gęstością objętościową $62 \mathrm{~kg} / \mathrm{m}^{3} .{ }^{33}$

Dotychczasową wiedzę o nanorurkach jako magazynach wodoru, można podsumować w następujący sposób:

- nanorurki o strukturze otwartej i heksagonalnym uporządkowaniu wykazują w temperaturze pokojowej wyższa pojemność sorpcyjna niż jakiekolwiek inne węgle aktywne,

- efektywność absorpcji zależy od średnica nanorurek i odległości między nimi,

- w niskiej temperaturze uzyskuje się wysoką absorpcje wodoru,

- nanorurki dotowane metalami mają dużą zdolność sorpcyjna w temperaturze pokojowej i przy ciśnieniu atmosferycznym. ${ }^{34}$

Nie ma jeszcze opracowanych warunków bezproblemowej pracy dla zastosowania nanorurek jako materiałów magazynujących wodór w sposób odwracalny. Wadą tych materiałów są także wysokie koszty.

Wśród metod magazynowania wodoru można wymienić jeszcze sposoby jego pozyskiwania proponowane i badane w skali laboratoryjnej:

— odwodornienie dekaliny do naftalenu, w reakcji $(16)^{35}$ :

$\mathrm{C}_{10} \mathrm{H}_{18} \stackrel{210^{\circ} \mathrm{C}}{\longrightarrow} \mathrm{C}_{10} \mathrm{H}_{8}+5 \mathrm{H}_{2}$

W wyniku reakcji uwalniane jest 7,2\% $\mathrm{m} / \mathrm{m} \mathrm{H}_{2}$.

- odwodornienie metylocykloheksanu do toluenu, w reakcji $(17)^{36}$ :

$\mathrm{C}_{6} \mathrm{H}_{11} \stackrel{320^{\circ} \mathrm{C}}{\longrightarrow} \mathrm{C}_{6} \mathrm{H}_{5}-\mathrm{CH}_{3}+3 \mathrm{H}_{2}$

Reakcja zachodzi pod ciśnieniem atmosferycznym uwalniając $6,1 \% \mathrm{~m} / \mathrm{m} \mathrm{H}_{2}$. rozkład borowodorków aminowych bogatych w wodór $\left(\mathrm{NH}_{3} \mathrm{BH}_{3}\right)$, reakcja dwuetapowa (18) i (19)

31 F. L. Darkrima, P. Malbrunot, G. P. Tartaglia, Review of hydrogen storage by adsorption in carbon nanotubes, Hydrogen Energy, 2002, nr 27, s. 193.

32 Departament of Energy-Departament Energii

33 F. L. Darkrima, P. Malbrunot, G. P. Tartaglia, Review of hydrogen storage by adsorption in carbon nanotubes, Hydrogen Energy, 2002, nr 27, s. 193.

34 J. Surygała, „Wodór jako paliwo”, WNT, Warszawa 2008, s. 91.

35 www1.eere.energy.gov.

36 Y. ОкаDA, Development of dehydrogenation catalyst for hydrogen generation in organic chemical hydride method, Hydrogen Energy, 2006, nr 31, s. 1347. 


$$
\begin{aligned}
& \left.\left\lfloor\mathrm{NH}_{3} \mathrm{BH}_{3}\right\rfloor_{(c)} \stackrel{120^{\circ} \mathrm{C}}{\longrightarrow} \mid \mathrm{NH}_{2} \mathrm{BH}_{2}\right\rfloor_{(s)}+H_{2(g)} \\
& \left.\left.\mid \mathrm{NH}_{2} \mathrm{BH}_{2}\right\rfloor_{x(s)} \stackrel{155^{\circ} \mathrm{C}}{\longrightarrow} \mid \mathrm{NHBH}\right\rfloor_{x(s)}+H_{2(g)}
\end{aligned}
$$

Reakcja zachodzi w dwóch etapach w jej wyniku uwalniane jest $13 \%(\mathrm{~m} / \mathrm{m})$ $\mathrm{H}_{2}$, jednak szybką komercjalizację reakcji boranu amonu uniemożliwia jego wysoka cena.

Rozważana jest także możliwość stosowania polihydroboranów, które są materiałami bogatymi w wodór i zdolnymi do jego uwalniania.

Koszty magazynowania wodoru szacowane w 2004 r. przedstawiono w tabeli 3.

Tabela 3. ${ }^{37}$ Szacowane koszty magazynowania wodoru (2004 r.)

\begin{tabular}{|l|c|c|}
\hline \multicolumn{1}{|c|}{ Metoda magazynowania } & Zużycie energii, kWh/kg & Koszty systemowe, USD/kWh \\
\hline Wodorki chemiczne & 1,4 & 8 \\
Wodorki kompleksowe & 0,8 & 16 \\
Wodór ciekły & 1,7 & 6 \\
Wodór gazowy (700 atm) & 1,6 & 18 \\
Wodór gazowy (350 atm) & 1,9 & 15 \\
\hline
\end{tabular}

Na koszty magazynowania wodoru maja wpływ następujące składowe:

- maksymalna ilość magazynowanej energii,

- ilość energii potrzebna do magazynowania urządzeń magazynowych,

- średnio 50\% wykorzystania pojemności magazynowej,

- średnio 360 cykli ładowanie/rozładowanie w ciągu roku,

- $14 \mathrm{~h}$ pracy urządzeń załadowczych dziennie,

- amortyzacja $15 \%$,

- koszty obsługi osobowej 2,5\%,

- weryfikowane na bieżąco koszty energii elektrycznej,

- koszty sorbenta węglowego.

W przypadku magazynowania $\mathrm{H}_{2}$ w formie cieczy zakłada się zużycie $30 \ldots 40 \%$ magazynowanej energii.

\footnotetext{
37 Hydrogen Storage Sub-Program Overview, Progres Raport, 2004.
} 


\section{Bibliografia}

H. Figiel., Paja A., „Wodór w związkach międzymetalicznych typu faz Lavesa ziem rzadkich z manganem", Przemysł Chemiczny 2005, 84, nr 11,

Gardziński W., Molenda J., Przemysł Chemiczny 2005, 84, nr 11,

Huczko A., „Magazynowanie wodoru w fulerenach i nanorurkach węglowych”, Przemysł Chemiczny 2002, 81, nr 1,

Jastrzębska G., „Odnawialne źródła energii i pojazdy proekologiczne”, WNT, Warszawa 2007,

Kijeński J., Chemik 2007, nr 1,

Kijeński J., „Dlaczego wodór?”, Przemysł Chemiczny 2005, 84, nr 11,

Lewandowski W., „Proekologiczne odnawialne źródła energii”, WNT, Warszawa 2007,

Lublińska K., Zagórski A., Spychalski W., Kurzydłowski K.J., „Tworzywa konstrukcyjne w technologiach wodorowych", Przemysł Chemiczny 2005, 84, nr 11,

Merkisz J., Pielucha I., „Alternatywna napędy pojazdów”, Wydawnictwo Politechniki Poznańskiej, Poznań 2007,

Molenda J., „Gaz ziemny. Paliwo i surowiec”, WNT, Warszawa 1994,

Narkiewicz U., Ekiert E., Arabczyk W., Przemysł Chemiczny 2007, 86, nr 9,

Nowacki J.P., „Wodór - nowy wektor energii” PWN, Warszawa 1966,

Paradowski K, Zagórski A., Lublińska K., Kurzydłowski metodami.J., „Ocena metodami nieniszczącymi degradacji wodorowej stali niskostopowych”, Zeszyty Naukowe Politechniki Rzeszowskiej. Budownictwo i Inżynieria Środowiska 2006,

Pińkowska K., Przemysł Chemiczny 2007, 86, nr 7,

Rudkowski M., „Polskie silniki i pojazdy wodorowe”, Przemysł Chemiczny 2005, 84, nr 11,

Schmidt J., Kurzydłowski K.J., Mechanik 2002, nr 12,

Smoliński A., Howaniec N. (2006) Wodór - czysty nośnik energii (cz. II). Czysta energia 9, (59),

Staliński B., Terpiłowski J., „Wodór i wodorki”, WNT, Warszawa 1987,

Tengler Sz., „Współczesne metody chemicznej przeróbki węgla”, PWN, Warszawa 1981,

Urbanie K., Chemik 2007, nr 1,

Zieliński J., Urbaniec K., Machowska Z., Przemysł Chemiczny 2007, 86, nr 12,

Surygała J., „Wodór jako paliwo”, WNT, Warszawa 2008,

Chang J.S., Lee K.S., Lin P.J., „ Biohydrogen production with fixed-bed bioreactors”, Hydrogen energy 2002, nr 27

Urbaniec K., Chemik 2007, nr 1,

Pińkowska K., Przemysł Chemiczny 2007, 86, nr 7,

Zieliński J., Urbanie K., Machowska Z., Przemysł Chemiczny 2007, 86, nr 12,

Jędrzejowska-Cicińska M., Kozak K., Krzemieniowski M., Energia i ekologia, 2007, nr 4,

Smoliński A., Howaniec N., Wodór - czysty nośnik energii (cz. II). Czysta energia, 2006, nr 9,

Tomczyk P., Polityka energetyczna, 2004, nr 7,

Wald M. L., Świat Nauki, 2004, t. 154,

Kulazynski M., Cadek W., Hydrogen storage, www.hyweb.de,

Takeichi N., Senon H., Hybrid Hydrogen storage wessel, Hydrogen Energy, 2003, nr 28,

Satyapal S., Petrovic J., Wodór w baku, Świat nauki, 2007, nr 5,

Aceves S. M., Martinez-Frias J., Garcia-Villazana O., Analytical and experimental evaluation of insulated pressure vessels of cryogenic hydrogen storage, Hydrogen Energy 2000, nr 25,

Schwarz, R.B. (1997) Critical Parameters in the Performance of the Hydrogen Storage Material. Los Alamos National Laboratory, http://itri.loyola.edu/nano/us_r_n_d/04_06.htm,

Akiba E., Japan's Global Vision for Hydrogen Storage Technology and the Hydrogen Economy, Gordon Research Conference, Hydrogen - metal Systems 14 July 2005,

Hydrogen Storage Material Work Shop Proceedings, Argonne National Laboratory, Argonne, IL, 2002, USA, 
Fakioglu E., Yurum Y., Veziroglu T. N., A review of Hydrogen storage systems based on boron and its compounds, Hydrogen Energy, 2004, nr 29,

Zhang Q., Smith G., Wu Y., Catalytic hydrolysis of sodium borohydridein autu-thermal fixed-bed reactor, Hydrogen Energy, 2006, nr. 31,

Huczko A., „Magazynowanie wodoru w fulerenach i nanorurkach węglowych”, Przemysł Chemiczny 2002, 81, nr 1,

Zuttel A., Smolan P., Hydrogen storage in carbon nanostructures, Hydrogen Energy, 2002, nr 27,

Darkrima F. L., Malbrunot P., Tartaglia G. P., Review of hydrogen storage by adsorption in carbon nanotubes, Hydrogen Energy, 2002, nr 27,

Okada Y., Development of dehydrogenation catalyst for hydrogen generation in organic chemical hydride method, Hydrogen Energy, 2006, nr 31,

Hydrogen Storage Sub-Program Overview, Progress Raport, 2004,

Sidorov V. P.,. Dorofeev S. B, Influence of initial temperature, dilution and scale on DDT conditions in hydrogen-air mixtures, Archivum Combastion, 1998, nr 18,

James B. D., Distributed Hydrogen Fueling Systems Analysis, DOE Progress report FY 2002, Arlington (Virginia USA),

Pehr K., Sauerman P., Liquide Hydrogen for motor vehicles-the World First public $\mathrm{LH}_{2}$ filling station, Hydrogen Energy, 2001, nr 26,

www.kpk.gov.pl,

www.ec.europa.eu.pl,

www1.eere.energy.gov,

www.hydropark.ca.sandia.gov

www.wikipedia.org.pl,

www.slcj.uw.edu.pl,

www.nw.pwr.wroc.pl,

www.icwarszawa.internetdsl.pl,

www.giph.com.pl,

www.ekoenergia.pl,

www.imine.polsl.pl,

www.bmwauto.net.pl,

www.autocentrum.pl,

www.moto.wp.pl,

www.frazpc.pl,

www.ogniwa-paliwowe.com.pl,

www.infobus.com.pl,

www.laboratoria.net.pl,

www.flota.com.pl,

www.auto-moto.pl,

www.ndtest.com.pl,

www.gigawat.net.pl,

www.hq.nasa.gov. 


\section{The analysis of biohydrogen fuel storing processes}

\section{SUMMARY}

Possibilities of biohydrogen fuel storing were represented. Hydrogen can be store in gas, liquid or constant form. Technological, material and economic hydrogen storing determinates were shown. Experiments and researches on finding optimal hydrogen storage methods have been taken into consideration.

Keywords : biohydrogen, biofuels, metal hydrides, carbon materials, hydrogen 